Włodzimierz Cieciura

(Uniwersytet Łódzki)

\title{
Polityka religijna w Chińskiej Republice Ludowej Komunistyczne państwo a religia
}

Od kiedy w 1949 r. proklamowano w Chinach powstanie komunistycznego państwa zmonopolizowanego przez Partię, dla wyznawców religii nastały trudne czasy. Polityka partyjnego państwa i samej Partii zmieniała się i ewoluowała od dość łagodnej $\mathrm{w}$ ciagu pierwszych 5 lat istnienia komunistycznego rządu, poprzez gwałtowne represje w trakcie tzw. „demokratycznej reformy instytucji religijnych” z lat pięćdziesiątych ubiegłego wieku i ,kampanii przeciwko prawicowcom" w latach 1957-1958, aż po politykę całkowitej eliminacji religii jako takiej podczas rewolucji kulturalnej. Można zauważyć pewne cechy wspólne dla wszystkich etapów ewolucji tej polityki aż po dziś dzień. Cechą charakterystyczną polityki religijnej ChRL we wszystkich historycznych fazach jest głębokie przekonanie Partii Komunistycznej i jej przywództwa o dziejowej nieuchronności zaniku religii jako przeżytku feudalnego oraz kapitalistycznego porządku społecznego. Zgodnie $\mathrm{z}$ dominującym w ChRL dyskursem marksistowsko-leninowskim oraz myślą Mao Zedonga, religia stopniowo będzie zanikać w miarę rozwoju nowego ustroju i wraz z pojawieniem się socjalizmu, a następnie komunizmu.

Od wczesnych etapów istnienia Komunistycznej Partii Chin kwestia religii zajmowała ważne miejsce w doktrynie partyjnej. Od „rewolucyjnych baz” KPCh w czasach wojen domowych i wojny z Japonią aż po ChRL centralnym narzędziem $\mathrm{w}$ stosunkach $\mathrm{z}$ religią była i pozostaje nadal tzw. ,polityka wolności wyznania" (xinyang ziyou), zapisana w konstytucjach Chin Ludowych z 1954, 1975, 1978 i 1982 r. Sformułowana w tych dokumentach zasada „wolności od i do wyznawania religii" jest często przywoływana przez przedstawicieli ChRL jako główny argument, mający udowodnić tolerancyjność i pobłażliwość partyjnego państwa nawet dla takich „przeżytków” jak religia. Równocześnie w wielu tych wypowiedziach kładzie się nacisk na wolność od religii i wydaje się, że partyjne państwo większość swych wysiłków koncentruje właśnie na chronieniu obywateli przed zgubnymi jej wpływami.

Od momentu zdobycia władzy przez KPCh partyjne państwo stworzyło rozbudowany system kontroli działalności grup religijnych, zdominowany przez kadrowców (ganbu), lojalnych wobec Partii i rządu. Utworzono centralne 
urzędy, w gestii których znalazło się prowadzenie polityki „,wolności wyznania” i poddano je kontroli Biura Zjednoczonego Frontu KC KPCh, które do dziś stanowi oficjalną płaszczyznę kontaktów na linii Partia - religie. Od początku istnienia ChRL Partia energicznie wkroczyła na obszary pozostające wcześniej w wyłącznej gestii grup religijnych, organizując szereg oficjalnych stowarzyszeń, poddanych ścisłej kontroli organizacyjnej Zjednoczonego Frontu i Biura Spraw Religijnych (Guojia Zongjiao Shiwu Ju), pełniącego funkcję ministerstwa ds. religii ${ }^{1}$. Oprócz głębokiego przekonania kierownictwa Partii o nieprzystawalności religii do socjalistycznego państwa, religię utożsamiono także z „imperializmem" w przypadku chrześcijaństwa oraz z ,feudalizmem” w przypadku buddyzmu, taoizmu i islamu ${ }^{2}$. Jednym $\mathrm{z}$ najczęściej pojawiających się $\mathrm{w}$ oficjalnych wystąpieniach i publikacji sformułowań stała się ,infiltracja religijna" (zongjiao shentou), którą nazwano działalność misjonarzy katolickich i protestanckich oraz próby kontaktów cudzoziemców z wyznawcami religii w Chinach. Wielu misjonarzy oskarżono o szpiegostwo na rzecz Stanów Zjednoczonych i pokonanego Guomindangu Chiang Kai-szeka. W sierpniu 1951 r. aresztowano biskupa diecezji Yixian położonej na zachód od Pekinu, Tarcisio Martinę, pod absurdalnym zarzutem uczestnictwa w spisku, mającym na celu zabicie Mao Zedonga w czasie uroczystości pierwszej rocznicy powstania ChRL. W nagłośnionym procesie skazano go na dożywotnie więzienie, co ułatwiło władzom rozpętanie nagonki na kościół katolicki w Chinach i wypędzenie we wrześniu 1951 r. nuncjusza apostolskiego, Antonio Riberiego. Innym katolickim dostojnikiem oskarżonym o szpiegostwo był amerykański biskup James Edward Walsh, wikariusz diecezji Jiangmen (czyli prowincji Guangdong) i kierownik Centralnego Biura Katolickiego w Szanghaju, aresztowany w 1959 r. i skazany na 20 lat więzienia ${ }^{3}$. Odmowa zerwania stosunków z Watykanem i poparcia dla utworzenia ,patriotycznego" stowarzyszenia katolickiego doprowadziła także do aresztowania w 1955 r. biskupa Szanghaju, Chińczyka Gong Pinmeia, który spędził 30 lat w więzieniu. Wraz z biskupem Gongiem aresztowano kilkaset osób, w tym licznych chińskich księży i zakonnic ${ }^{4}$. Niezwykłą skutecznością kościoła katolickiego w tworzeniu ponadnarodowych więzi i lojalności miał się interesować osobiście sam Mao Zedong, którego niepokoiły wytrwałość i wierność Watykanowi chińskich katolików5.

\footnotetext{
${ }^{1}$ Biuro ma własną stronę internetową: http://www.sara.gov.cn/

${ }^{2}$ B. L e u n g, China's Religious Policy: the Art of Managing Religious Activity. „The China Quarterly”, Dec. 2005/184, s. 895.

${ }^{3}$ Biskup Walsh został zwolniony z więzienia i wydalony z Chin w styczniu 1970 r. Był to gest dobrej woli ze strony maoistowskich Chin. Biskup to ostatni cudzoziemski misjonarz, który opuścił ChRL; http://kc4076.org/walshbio.PDF, (stan z 2.11.2007).

${ }^{4} \mathrm{http}: / /$ www.cardinalkungfoundation.org/biography/index.htm (stan z 3.11.2007).

${ }^{5}$ J. C h a n g, J. H a 11 i d a y, Mao. Warszawa 2007, s. 328.
} 
Wraz z uznaniem jednoznacznie negatywnych cech religii i instytucji religijnych państwo komunistyczne stworzyło podstawowy antagonizm, cechujący stosunki pomiędzy nim a wyznawcami religii, nie podzielającymi państwowej ideologii, opartej o marksizm. Intencje polityki religijnej państwa dobrze oddał szef Zjednoczonego Frontu w latach pięćdziesiątych Li Weihan: ,[...] podstawowa polityka Partii wobec religii jest polityką długoterminową, która musi być stosowana aż do momentu całkowitego zaniku religii”"

Jednym z pierwszych kroków na drodze do przejęcia pełnej kontroli nad sprawami religii było rozróżnienie religii jako zjawiska kulturowego od religii jako instytucji. Zainicjowana przez Zjednoczony Front w pierwszych latach istnienia ChRL taktyka tworzenia kontrolowanych przez państwo związków wyznaniowych była wyrazem tego rozróżnienia. Po wydaleniu z kraju większości cudzoziemskich misjonarzy, księży i innych „pracowników religijnych” (czemu sprzyjała m.in. antyimperialistyczna retoryka okresu wojny koreańskiej) państwo utworzyło dwa podległe sobie chrześcijańskie związki religijne Patriotyczne Stowarzyszenie Katolików Chin, odrzucające polityczne przywództwo papieża i kierowane przez prawowitego, mianowanego wiele lat wcześniej przez Watykan biskupa Pi Shushi, oraz Trzykrotnie Autonomiczny Komitet Protestantów Chin, odrzucający wszelkie podziały wyznaniowe i łączący wszystkich protestantów mieszkających w kraju w jedną grupę pod przywództwem dawnego biskupa anglikańskiego ${ }^{7}$. Wszystkich nie zgadzających się z decyzjami państwa chrześcijan zepchnięto do podziemia. Jednym z celowych działań Zjednoczonego Frontu oraz BSR było wzniecanie konfliktów wśród wyznawców celem skuteczniejszego przeprowadzania czystek obejmujących nieposłusznych duchownych. Prokomunistyczni działacze stowarzyszenia protestanckiego, tacy jak Wu Yaozong i biskup Ding Guangxun, podjudzali szeregowych wyznawców do denuncjowania opornych pastorów i kaznodziei, odmawiających współpracy z KPCh. Po ucieczce z kraju czołowych teologów protestanckich, Zhou Lianhua i Xie Fuya, kościoły protestanckie znalazły się pod całkowitą kontrolą państwa ${ }^{8}$.

Tę samą taktykę zastosowano także w przypadku trzech pozostałych religii, tworząc z lojalnych duchownych związki religijne buddyjski, taoistyczny i muzułmański. Zjazdy założycielskie tych stowarzyszeń, które miały miejsce w połowie lat pięćdziesiątych skupiły działaczy wiernych KPCh, pozostawiając

${ }^{6}$ Cyt. za B. Le u n g, op. cit.

7 „Potrójna autonomia” odnosi się do zasad samodzielnego zarządzania (zi zhi), samodzielnego propagowania (zi chuan) oraz samodzielnego utrzymania (zi yang) związku wyznaniowego chińskich protestantów. Oczywiście autonomia dotyczyła niezależności od ośrodków zagranicznych.

${ }^{8}$ B. L e u n g, op. cit., s. 899. 
niechętnych poza oficjalnym systemem, narażonych na represje ${ }^{9}$. Przyjęte przez zjazdy założycielskie związków religijnych deklaracje zawierały przyrzeczenia politycznej lojalności wobec linii partyjnej i komunistycznego państwa. W niektórych przypadkach deklaracje te zawierały sformułowania wrogie wobec religii, nie pozostawiając złudzeń co do faktycznej roli tych organizacji. Podobnie jak w przypadku protestantyzmu, do organizacji tych weszły wszelkie odłamy religijne, mające utworzyć zjednoczoną organizację wolną od „sekciarskich" podziałów.

Jednym z ważnych elementów systemu podporządkowania sobie pięciu związków religijnych było utworzenie pod ich auspicjami centralnych uczelni religijnych, kształcących nowy ,personel religijny” zgodnie z wytycznymi Partii, zarówno w sferze politycznej i ideologicznej, jak i teologicznej - wpływając na interpretowanie wybranych drażliwych kwestii zgodnie z linią polityczną państwa. Absolwenci tych uczelni mieli zastapić niepewnych poprzedników i trudno się oprzeć wrażeniu, że mieli być bardziej urzędnikami partyjnego państwa niż osobami duchownymi.

Tworząc lojalne związki religijne, obejmujące swoją kontrolą pięć religii, pozostawiono poza systemem przedstawicieli innych wyznań, takich jak prawosławie. Nieposiadające zorganizowanych struktur religie (chiński kult przodków, chińska religia ludowa czy animistyczne wierzenia grup etnicznych w Chinach południowych) uznano za „feudalne przesądy” (fengjian mixin) i jako takie z góry przeznaczono do likwidacji.

W obaleniu tradycyjnych przywódców religijnych pomogła reforma rolna, która pozbawiła buddyjskie i taoistyczne świątynie i klasztory oraz kościoły, meczety i bractwa sufickie ich posiadłości ziemskich i tym samym zniszczyła źródła utrzymania „feudalnych” duchownych. Zarząd nad świątyniami odebrano dotychczasowym przeorom, księżom czy imamom i powierzono świeckim „komitetom zarządzającym”, nominowanym w sposób niejawny przez rządowe stowarzyszenia. W latach pięćdziesiątych przeprowadzono $\mathrm{z}$ aprobatą pięciu stowarzyszeń „demokratyczną reformę instytucji religijnych” (Zongjiao Zhidu Minzhu Gaige), która w drastyczny sposób zredukowała liczbę przybytków religijnych, uznanych za coraz mniej potrzebne społeczeństwu zmierzającemu w stronę komunizmu. Reforma ta w pierwszej kolejności dotknęła buddystów i taoistów z obszarów etnicznie hańskich, gdzie jej rozpoczęcie ogłoszono już w czerwcu 1951 r. Pierwszym aktem było odebranie klasztorom i świątyniom

${ }^{9}$ Jako pierwszy powołany został do życia Muzułmański Związek Wyznaniowy (Zhongguo Yisilanjiao Xiehui) utworzony w maju 1953. Dwa tygodnie później powstał Buddyjski Związek Religijny (Zhongguo Fojiao Xiehui). Protestancki Patriotyczny Komitet Ruchu Potrójnej Autonomii (Zhongguo Jidujiao Sanzi Aiguo Yundong Weiyuanhui) utoworzono w lipcu 1954, Taoistyczny Związek Religijny (Zhongguo Daojiao Xiehui) w kwietniu 1957 r., Katolicki Patriotyczny Związek Religijny (Zhongguo Tianzhujiao Aiguo Hui) w lipcu tego samego roku. 
ziemi oraz skierowanie duchownych do „dobrowolnej” pracy na roli ${ }^{10}$. Mnichom zakazano wędrowania pomiędzy świątyniami, które miały zostać przekazane do „publicznego użytkowania”. W czerwcu 1951 r. Komitet Centralny KPCh wydał instrukcję nakazującą pozostawienie w miastach jedynie nielicznych większych świątyń, w których mnisi i mniszki mogliby korzystać z polityki „wolności wyznania"11. Położono równocześnie nacisk na wzmocnienie działalności propagandowej i reedukacyjnej oraz zdławienie ,ukrytych szpiegów i agentów kontrrewolucji i imperializmu" działających wśród duchownych. O ile duże świątynie miały szanse przetrwania, o tyle tysiące rozsianych po całym kraju małych świątyń i kapliczek poświęconych kultom ludowym uznano za miejsca „praktyk zabobonnych”, a opiekujących się nimi duchownych - za wyzyskiwaczy, których całkowicie wyjęto spod prawa. Znajdujące się w niemal każdej wsi świątynie lokalnych bóstw opiekuńczych (Nainai Miao), bóstwa ognia (Huoshen Miao), świątynie Guan Yu oraz kapliczki bóstwa bogactwa (Caishen Miao) zostały sklasyfikowane jako pozostałości feudalnych przesądów i tym samym przeznaczone do likwidacji ${ }^{12}$.

$\mathrm{Na}$ obszarach etnicznie niehańskich reforma objęła przede wszystkim wyznawców islamu, buddyzmu tybetańskiego oraz buddyzmu Theravada. Na obszarach muzułmańskich rozpoczęcie reformy ogłoszono późno, dopiero w $1958 \mathrm{r}$. Strategiczne położenie zdominowanych przez muzułmanów prowincji północnego zachodu i silne lokalne tradycje militarystyczne wymagały ostrożności w podejściu do miejscowych muzułmanów. Dopiero po ugruntowaniu się reżimu Pekin zdecydował się na rozpoczęcie akcji drastycznego zmniejszenia liczby meczetów oraz innych miejsc muzułmańskich praktyk religijnych. W ciągu dwóch lat, w Ningxia, nominalnie autonomicznym regionie muzułmańskiej mniejszości etnicznej Hui, zamknięto, zlikwidowano bądź całkowicie zburzono (co było najczęstszą praktyką) $96 \%$ meczetów $^{13}$. W trakcie przeprowadzania reformy objęto także czystką dotychczasowych działaczy związku wyznaniowego, pozostawiając w nim jedynie lojalnych rządowi aparatczyków, takich jak przewodniczący związku Burhan Szahidi, komunista tatarskiego pochodzenia.

Z podobnych przyczyn również buddyzm tybetański objęty został „reformą” później niż religie na obszarach etnicznie hańskich. Po wkroczeniu chińskiej armii do Tybetu w 1950 r. władze komunistyczne skoncentrowały się na zapewnieniu sobie kontroli nad tym obszarem, unikając antagonizowania miej-

${ }^{10} \mathrm{He}$ H u s h e n g, Zhongguo Gongchandang Zongjiao Zhengce Yanjiu [Studia nad polityką religijną Komunistycznej Partii Chin], Beijing 2004, s. 126-127.

${ }^{11}$ Zhonggong Zhongyang Guanyu Han Minzu Zhong Fojiao Wenti de Zhishi [Instrukcja KC KPCh odnośnie do problemu buddyzmu wśród Hanów], 16.06.1951; cyt. za: He H u s h e n g, Zhongguo..., s. 118-119.

${ }^{12} \mathrm{He} \mathrm{Hu}$ s heng, Zhongguo..., s. 128.

${ }^{13} \mathrm{Li} \mathrm{X}$ inghua, et al., Zhongguo Yisilanjiao Shi [Historia islamu w Chinach], Pekin 1998, s. 844. 
scowej ludności. Początkowo utrzymano wyjątkowy status Dalajlamy i Panczenlamy, co gwarantowało siedemnastopunktowe porozumienie między Tybetańczykami a rządem chińskim z 23 maja 1951 r. Jednak od początku władze komunistyczne zakładały głęboką przemianę systemu gospodarczego i politycznego Tybetu, którą miano osiagnąc na drodze bezkrwawych reform ${ }^{14}$. Rozpoczęcie reformy ogłoszono w Tybecie dopiero w 1959 r., gdy cały region objęło antychińskie powstanie, spowodowane głównie polityką konfiskaty zbóż i szerzącym się głodem wywołanym klęską Wielkiego Skoku. W trakcie tłumienia powstania przez wojsko chińskie zniszczono większość świątyń tybetańskich, a mnichów zmuszono do porzucenia stanu duchownego. Wraz z ucieczką Dalajlamy (1959) nastąpił faktyczny koniec kulturowej niezależności Tybetu i tradycyjnego systemu społeczno-religijnego.

„Kampania przeciwko prawicowcom” z lat 1957-1958 zakończyła proces usuwania niepewnych duchownych, dotychczas nie atakowanych. Objęła ona swoim zasięgiem także członków lojalnych stowarzyszeń, zdradzających zbyt konserwatywne poglądy. Wielu $\mathrm{z}$ nich wysłano do obozów reedukacji przez pracę, skąd wielu już nie wróciło, umierając z głodu w czasie klęski spowodowanej niepowodzeniem Wielkiego Skoku. Opowieści o zaginionych wówczas powszechnie szanowanych duchownych często słyszy się z ust wierzących w całym kraju. Radykalizacja polityki religijnej szczególnie szybko następowała po Czwartej Ogólnochińskiej Konferencji Roboczej ds. Religii na przełomie sierpnia i września 1957 r. Wszystkim związkom religijnym nakazano wówczas zwołanie zjazdów i potępienie wskazanych przez władze duchownych. W okresie Wielkiego Skoku dużą część duchownych zmuszono do ciężkich prac fizycznych, a ocalałe budynki świątynne „dobrowolnie” przekazano na cele produkcyjne. Rozpoczęto również tworzenie „eksperymentalnych” wolnych od religii wsi oraz nadal posługiwano się retoryką atakowania wrogów i obcych szpiegów w szeregach duchowieństwa wszystkich wyznań ${ }^{15}$.

Po fiasku Wielkiego Skoku naciski na religię nie uległy złagodzeniu. Choć zarówno reforma instytucji religijnych, jak i Wielki Skok niemal zupełnie sparaliżowały życie religijne w kraju, władze kontynuowały politykę wymierzoną w duchownych i opornych wiernych. Kolejna konferencja robocza ds. religii, obradująca na przełomie 1962 i 1963 r., w przyjętym sprawozdaniu oceniła, że „elementy kontrrewolucyjne” istniejące pod przykrywką działalności religijnej zdołały odzyskać w czasie dwóch lat po zakończeniu Wielkiego Skoku swoje wcześniejsze wpływy i siłę. Uznano wobec tego, że należy wzmóc wysiłki propagandowe wymierzone w „osobistości” religijne i objąć je kampanią edukacji socjalistycznej oraz kampanią edukacji „trzech izmów” (Sange Zhuyi Jiaoyu Yundong) - patriotyzmu, internacjonalizmu i socjalistycznej nauki

\footnotetext{
${ }^{14} \mathrm{He} \mathrm{Hu}$ sheng, Zhongguo..., s. 135.

${ }^{15}$ Ibidem, s. 140.
} 
klasowej. Zwykłych wyznawców od spraw religii miały odciągnąć zajęcia z „,wiedzy i kultury naukowej”, wytwarzające właściwy materialistyczny światopogląd. W sierpniu 1963 r. BSR zorganizowało konferencję, na którą ściągnięto przeszło 550 przedstawicieli duchowieństwa, których poinformowano o ,zdjęciu pokrywy z walki klas” (Jie Jieji Douzheng Gaizi). Eufemizmem tym określano rozpoczęcie kolejnej fali represji, tym razem pod pretekstem „kampanii edukacji socjalistycznej”. Jej organizowaniem zajęli się pracownicy regionalnych biur ds. religii, koordynujący prześladowania duchownych i opornych wyznawców ${ }^{16}$.

W okresie rewolucji kulturalnej polityka wobec religii przybrała jeszcze bardziej ekstremistyczny charakter. Pod przywództwem radykalnych stronników Mao Zedonga przystąpiono do całkowitej eliminacji resztek religii $\mathrm{z}$ życia społecznego, niszcząc bądź zamykając niemal wszystkie obiekty religijne w kraju. Wzorem radzieckim, w przydatnych i niezniszczonych przez Czerwoną Gwardię świątyniach urządzano magazyny, warsztaty bądź inne zakłady (praktykę tę stosowano już wcześniej, na mniejszą skalę, w czasie Wielkiego Skoku). W ciągu pierwszych pięciu miesięcy rewolucji kulturalnej, w czasie niszczenia „czterech staroci”, zburzono większość świątyń. W październiku 1966 r. BSR przeprowadziło w 25 dużych i średnich miastach rozpoznanie zniszczeń - z 822 istniejących w nich przed rozpoczęciem rewolucji kulturalnej świątyń i kościołów zniszczono w pięć miesięcy $754^{17}$. W całym kraju pozostawiono zaledwie kilka świątyń w Pekinie przeznaczonych wyłącznie na użytek cudzoziemców, a uczelnie religijne zlikwidowano. Rozwiązano także wszystkie związki religijne, a maoistowska konstytucja z 1975 r. powtarzała już tylko puste hasło o ,wolności wyznania” wraz z innymi martwymi prawami obywateli ${ }^{18}$.

Powrót do polityki „wolności wyznania” nastapił stopniowo po $1978 \mathrm{r}$. i wprowadzeniu reform gospodarczych i społecznych. Powrócono do struktur związków religijnych, kontrolowanych przez Zjednoczony Front i BSR. Przywrócenie części przywilejów dla grup religijnych motywowane było m.in. chęcią pozyskania inwestycji zagranicznych, a częściowo także chęcią uspokojenia napięć społecznych. Oficjalna doktryna krytyki poprzedniego okresu dotyczyła także „lewackich ekscesów” na polu religii. Wielu skazanych w trakcie kampanii przeciwko prawicowcom i rewolucji kulturalnej duchownych i wiernych oczyszczono z zarzutów i rehabilitowano - często pośmiertnie. Uznając fakt utraty zaufania większej części wiernych do dotychczasowych związków

${ }^{16}$ Ibidem, s. 142.

${ }^{17}$ Ibidem, s. 144.

${ }^{18}$ Patrz art. 28 Konstytucji ChRL z 1975 r.: „Obywatele mają prawo do wolności słowa, wolności komunikowania się, wolności wydawniczej, wolności zgromadzeń, wolności zawiązywania organizacji, wolności podróżowania, wolności demonstrowania, strajkowania. Mają również prawo do wolności wyznawania bądź nie wyznawania religii oraz wolność propagowania ateizmu". 
religijnych, wprowadzono w nich zmiany kadrowe, często przywracająć osoby wcześniej usunięte jako politycznie niepewne. W przypadku Patriotycznego Stowarzyszenia Katolików Chin, które straciło w dużym stopniu zaufanie wiernych, nadgorliwie zwalczając podziemny kościół uznający zwierzchnictwo papieża, utworzono oprócz niego dwie nowe organizacje katolickie - Katolicki Komitet Administracyjny i Konferencję Biskupów Katolickich Chin.

Wyjątkiem na tle innych związków religijnych, odtworzonych dopiero po 1980 r., był Chiński Związek Buddyjski, któremu zezwolono na reaktywację już w 1972 r., licząc na pozytywną reakcję władz japońskich, z którymi normalizowano wówczas stosunki ${ }^{19}$. Decyzja ta pokazuje, że w ChRL polityka wobec religii często stanowi funkcję polityki zagranicznej.

Po zainicjowaniu reform gospodarczych Zjednoczony Front przywrócił politykę kooptowania wyznawców religii i ich przywódców do procesu modernizowania kraju. Nonkonformiści często okazywali się cennymi dla kraju specjalistami i jednym ze sposobów odzyskania ich zaufania do Partii Komunistycznej i jej państwa było przywrócenie polityki wolności wyznania. Równocześnie Partia nie zamierzała odchodzić od marksistowskiego przekonania o nieuchronnym obumieraniu religii w miarę budowy komunizmu. To spojrzenie utrzymuje się w KPCh do dziś.

Po wyjściu z więzienia wielu duchownych natychmiast przystępowało do działalności religijnej, nawet pomimo braku ogólnych uregulowań. W niektórych przypadkach zdezorientowane władze ponownie aresztowały wypuszczonych z więzień, np. jezuitów z Szanghaju, aresztowanych powtórnie za „działalność religijną" w $1981 \mathrm{r}$.

Przez cały okres reform gospodarczych nie skodyfikowano prawa odnośnie do religii $\mathrm{w}$ jeden zwarty dokument, posiłkując się tymczasowymi rozporządzeniami i regulacjami. Pierwszym z takich dokumentów i równocześnie wzorem dla wszystkich analogicznych był dokument nr 19 z 1982 r., który w intencji miał regulować sprawy wolności religii, aż do czasu jej nieuchronnego zaniku ${ }^{20}$. $\mathrm{W}$ duchu nowej epoki proces ten starano się oszacować realistycznie, zakładając, że potrwa on „długo" i deklarowano, że nie należy go brutalnie przyspieszać. Dokument omawia partyjną politykę „zdobywania zaufania, zjednaczania i politycznego edukowania personelu religijnego" oraz naprawy niesprawiedliwości popełnionych przez Partię. Powtarza także wcześniejsze zasady kształce-

${ }^{19}$ H. H. L a i, Religious Policies in Post-Totalitarian China: Maintaining Political Monopoly over a Reviving Society, „Journal of Chinese Political Science”, Spring 2006, Vol. 11, No. 1. H e $\mathrm{H}$ u s h e n g, Zhongguo..., s. 145.

${ }^{20}$ Obowiązująca konstytucja ChRL z 1982 r. w art. 36. powtarza formułkę o prawie do „wolności wyznania” oraz ,normalnych praktyk religijnych”. Brak jasnej definicji tych pojęć daje władzom wolną rękę w podejmowaniu arbitralnych decyzji w sferze religii. Patrz: E. R. C a r 1 s o n, China' New Regulations on Religion: A Small Step, Not a Great Leap, Forward, „Brigham Young University Law Review”, 2005. 
nia lojalnych wobec władzy duchownych oraz konieczność udzielenia wsparcia wspólnotom religijnym w odbudowywaniu świątyń i odzyskiwaniu mienia. Równocześnie ponownie ostrzega przed ,religijną infiltracją” i zaleca ostrożność w kontaktach z zagranicznymi grupami religijnymi. Dokument jasno formułuje zakaz praktykowania religii i wszelkich wierzeń przez członków Partii. Dokument nie sprecyzował jasno różnicy pomiędzy „prawowierną religią” a „feudalnym przesądem” i „szkodliwym kultem” (xiejiao). Za dokumentem nr 19 brak tego istotnego rozróżnienia powtarzają kolejne regulacje, narażając wszystkie aspirujące do większej autonomii grupy i wyznania na stygmatyzację ze strony państwa, a tym samym - stworzenie prawnych podstaw do prześladowań.

Choć w ogólnym zarysie dokument nr 19 stanowił zerwanie z radykalizmem rewolucji kulturalnej, to pełen był sprzeczności, które ujawniły się w trakcie stosowania jego zapisów przez lokalne kadry w kraju. Przede wszystkim zalecenia tolerancji dla grup religijnych kłóciły się z wymogami utrzymania ścisłej kontroli Partii nad nimi i ich wszelkimi działaniami. Spowodowało to, że dokument został przyjęty nieufnie przez wyznawców religii, podejrzewających nieszczere intencje jego twórców. O tym, że jego zapisy pozostały w dużej mierze martwe przekonali się np. buddyjscy wieśniacy, których prośby o zbudowanie świątyń w ich wsiach zostały odrzucone, podczas gdy rząd zbudował 142 własne świątynie wyłącznie w miejscach atrakcyjnych turystycznie. Sekcja VI dokumentu, polecająca zwrot majątku wspólnotom religijnym, została zignorowana przez miejscowych kadrowców i do dziś większość majątku pozostaje pod kontrolą władz ${ }^{21}$.

Problemy z wprowadzaniem w życie postanowień dokumentu nr 19, brak wykwalifikowanych kadr partyjnych do prowadzenia delikatnej polityki religijnej oraz dziury prawne w samym dokumencie spowodowały, że życie religijne kraju odżyło pomimo trwającej niechęci Partii do religii jako takiej. Lata osiemdziesiąte były okresem gwałtownego powrotu dużej części chińskiego społeczeństwa do praktyk religijnych przy równoczesnym załamaniu ideałów komunistycznych, spowodowanym bolesnym procesem reform oraz partyjna dyktaturą. Duża część wierzących związała się ze wspólnotami pozostającymi poza kontrolą związków religijnych i w 1990 r. BSR przyznawało, że 70\% życia religijnego $\mathrm{w}$ kraju pozostaje poza jego kontrola ${ }^{22}$. Wzrost roli religii $\mathrm{w}$ życiu społecznym kraju najlepiej obrazują liczby. Z 300 kościołów katolickich w 1983 r. ich liczba wzrosła do 2100 w 1987 r., a liczba katolików z 3,3 mln w 1986 r. do ponad 12 milionów w 1994 r., zarówno członków kościoła „,patriotycznego", jak i nielegalnego. Liczba protestantów wzrastała równie szybko, osiagając 6 mln w 1993 r. i 14 mln w 2004 r.

\footnotetext{
${ }^{21}$ B. L e u n g, China's Religious Policy, s. 904.

${ }^{22}$ Ibidem, s. 905.
} 
Tak gwałtowny rozwój religii spowodował zaniepokojenie części przywódców partyjnych. Ze szczególnym niepokojem obserwowali oni rolę kościołów $\mathrm{w}$ procesie rozmontowywania systemu partyjnego w Europie Wschodniej i zaangażowanie Watykanu w zmiany polityczne w Polsce. W roku 1990 jeden z najwyższych przywódców partyjnych i szef Centralnej Komisji Doradczej KC KPCh, Chen Yun, skierował do sekretarza generalnego Partii, Jiang Zemina, osobisty list, zalecający zaostrzenie kontroli nad religią i przywrócenie kontroli Partii nad wszystkimi wyznawcami. W liście bardzo zaniepokojonego religijna infiltracja Chen przywoływał przykład innych krajów komunistycznych, gdzie religia odegrała dużą rolę w obaleniu rządów komunistycznych. Jiang rozesłał list to wybranych członków kierownictwa, dopisując własną uwagę, aby Partia podjęła stosowne środki zaradcze ${ }^{23}$. Bezpośrednio po stłumieniu ruchu demokratycznego w kraju problem kontroli religii wysunął się na plan pierwszy. Gwałtowny wzrost liczby wyznawców różnych religii, przemiany w Europie Wschodniej, wzrastające napięcie etniczne $w$ zdominowanych przez muzułmanów północno-zachodnich regionach Chin oraz w Tybecie - wszystko to przemawiało zdaniem przywódców za powrotem do twardej polityki religijnej. Wydarzeniem, które spowodowało wielkie obawy kierownictwa była szczególnie nielegalna konferencja niezależnych od rządu biskupów podziemnego kościoła katolickiego, zorganizowana w listopadzie 1989 r. w Shaanxi. Podczas tego spotkania utworzono samodzielną Konferencję Biskupów, która w ocenie rządu mogła stać się dynamiczną bazą dla kościelnej opozycji wobec oficjalnego Związku i samej Partii. KPCh nabrała przekonania, że w zaistniałej po 1989 r. sytuacji religia stała się po raz kolejny narzędziem ,infiltracji”, mającym w rezultacie obalić partyjne państwo i sprowadzić Chiny z socjalistycznej drogi ${ }^{24}$. W 1991 r. Rada Państwowa przyjęła dokument nr 6, nakładający ścisłą kontrolę państwa i partii na wszystkie praktyki religijne ${ }^{25}$. Zwolennikiem twardej linii wobec religii był wówczas premier Li Peng, który na konferencji roboczej ds. religii w grudniu $1990 \mathrm{r}$. wezwał do poddania religii znacznie silniejszej kontroli politycznej. Jiang Zemin odrzucił te sugestie, zapraszając na konferencję do Zhongnanhai przywódców pięciu związków religijnych i zapewniając ich, że polityka religijna partii pozostanie tolerancyjna dla oficjalnie uznanych religii oraz administrowana będzie w ramach ,zjednoczonego frontu” służącego reformom i otwarciu na świat ${ }^{26}$.

${ }^{23} \mathrm{C}$ h e n Y u n, Guanyu Gaodu Zhongshi Zongjiao Shentou Wenti de Xin, 4.04.1990. Tekst listu Chen Yuna i notatki Jiang Zemina: http://marx.ruc.edu.cn/zlk/1978-1998/13dz/39.rtf (stan z 19.10.2007).

${ }^{24}$ B. L e u n g, China's Religious Policy, s. 905.

${ }^{25}$ B. P. P it m a n, Belief in Control: Regulation of Religion in China, ,The China Quarterly", 2003, No. 174, s. 320-321.

${ }^{26}$ B. P. P it m a n, op. cit., s. 321. 
W pierwszej połowie lat dziewięćdziesiątych w północno-wschodnich Chinach narodził się masowy ruch quasi-religijny Falun Gong, wykorzystujący osobistą charyzmę swojego twórcy i przywódcy, Li Hongzhi (ur. 1951). Ruch ten łączący mistykę taoistyczną i buddyjską z tradycyjnymi ćwiczeniami oddechowymi rozwijał się dynamicznie zdobywając miliony zwolenników wśród ludności miejskiej, która zgodnie z partyjną doktryną miała stanowić forpocztę komunizmu w kraju. Wśród sympatyków Falun znalazło się także wielu członków Partii, co szczególnie zaniepokoiło władze.

Elementem zaostrzania polityki religijnej Partii i przywracania kontroli nad działalnością religijną był przyjęty w 1994 r. przez Radę Państwa dokument $\mathrm{nr} 145$ - Regulacje dotyczace administrowania miejscami dziatalności religijnej (Zongjiao Huodong Changsuo Guanli Tiaoli). Ustanawiał on obowiązek rejestracji w miejscowych Biurach Spraw Religijnych wszystkich miejsc używanych w celach religijnych. Przepis ten gwarantował legalność jedynie świątyniom i instytucjom lojalnym oficjalnym związkom, de facto spychając poza nawias prawa wszelkie pozostałe grupy. Powtórzono zapisy dokumentu nr 19 o konieczności przestrzegania linii partyjnej przez związki religijne oraz zachowaniu lojalności wobec rządu i programu budowy społeczeństwa socjalistycznego. Dokument ten został poprzedzony dokumentem $\mathrm{nr}$ 144, nakładającym bardzo ścisłe ograniczenia w sferze religijnej na cudzoziemców. Zabraniał im zakładania grup religijnych, miejsc kultu, szkół, propagowania doktryn religijnych oraz pozyskiwania wiernych. Wymierzony oczywiście $\mathrm{w}$,religijną infiltrację" - definiował jako cudzoziemców także obywateli Hongkongu i Makao, postrzeganych przez Partię jako główne zagrożenie ${ }^{27}$.

W 1995 r. na czele BSR stanął znany marksistowski ortodoks, Ye Xiaowen. Uczyniono go jednym $\mathrm{z}$ głównych odpowiedzialnych za wcielanie $\mathrm{w}$ życie polityki Jiang Zemina, ,przystosowania religii do socjalizmu” i nadzorowanie procesu ,zanikania religii”. W przedmowie do podręcznika pracy religijnej dla kadrowców w 1998 r. Ye adekwatnie nakreślił główne założenia polityki „,wolności religijnej” komunistycznych Chin: „wolność religijna, jak ją pojmujemy w Chinach, różni się od tej na Zachodzie. W naszym rozumieniu wolność wyznania nie jest nieograniczonym brakiem wszelkich barier, a przymus przestrzegania prawa i porządku nie jest ograniczeniem wolności religii”. W tym samym tekście Ye kontynuuje swój wywód: „religia jest iluzorycznym odbiciem zewnętrznych sił kontrolujących ludzkie życie powstałym w psychice człowie$\mathrm{ka}^{2}{ }^{28}$. W innym swoim tekście Ye Xiaowen podkreślał konieczność stosowania tzw. „trzech zdań” (san ju hua) Jiang Zemina na temat religii w codziennej

${ }^{27}$ Patrz: punkt 11 dokumentu 144 z 31 stycznia 1994 r., wydanego przez Radę Państwową ChRL. Zhonghua Renmin Gongheguo Guojingnei Waiguo Ren Zongjiao Huodong Guanli Guiding [Regulacje ChRL dot. Działalności Religijnej Cudzoziemców].

${ }^{28}$ Cyt. za: T. L a m b e rt, The Present Religious Policy of the Chinese Communist Party, „Religion, State \& Society” 2001, Vol. 29, No. 2. 
praktyce kadrowców: po pierwsze, wprowadzania zasad partyjnych w prowadzenie spraw wyznaniowych; po drugie, wzmacniania kontroli tychże zgodnie z przepisami prawa; po trzecie, aktywnego działania na rzecz dostosowania religii do socjalizmu ${ }^{29}$. Ye opowiedział się w swoim tekście za aktywną edukacją młodych pokoleń duchownych zgodnie $\mathrm{z}$ duchem materializmu historycznego i ateizmu, przeciwko aktywnym represjom i zmuszaniu wierzących do zaprzestania własnych praktyk. Jest to opinia charakteryzująca w dużej mierze stosunek Partii do kwestii religii: na drodze edukacji socjalistycznej i rozwoju społecznego przejdzie ona do historii i nie ma potrzeby przyspieszać tego procesu, bo szkodziłoby to wprowadzaniu reform gospodarczych, niepotrzebnie antagonizując ludność.

Najbardziej wyrazistym przejawem niechęci Partii do wszelkich zorganizowanych grup religijnych, pozostających poza jej kontrolą, była kampania zwalczania Falun Gong, zainicjowana w 1999 r. po serii demonstracji zwolenników Li Hongzhi przeciwko ograniczaniu ich swobód, z których największa, skupiająca ponad 10 tysięcy osób, miała miejsce przed Zhongnanhai w kwietniu 1999 r. Było to pierwsze masowe wystapienie w stolicy od czerwca 1989 r. i wywołało panikę władz. Obawiając się potencjalnych możliwości przewodzenia przez Falun milionom osób, nieuczestniczących w sukcesie gospodarczym Jiang Zemin, zainicjował rozprawę ze zwolennikami Falun, która trwa do dziś, bo zepchnęła rzesze członków ruchu do podziemia i zaszkodziła wizerunkowi ChRL na świecie. Partia oficjalnie uznała ruch za ,szkodliwą sektę" - xiejiao w lipcu i przystapiła do brutalnych prześladowan ${ }^{30}$. W bardziej otwartym i demokratycznym społeczeństwie ruch ten nie ma szans rozwoju na taką skalę. Na Tajwanie, gdzie władze prowadzą autentyczną politykę wolności wyznania, ruch przyciaggnął nie więcej niż 100 tysięcy osób ${ }^{31}$. O tym, że zgodnie z obawami KPCh to właśnie ruchy religijne stanowią zagrożenie dla jej monopolu może świadczyć aktywna działalność polityczna Falun, nawet po użyciu siły przez władze. Dziś ugrupowanie dociera do wielu Chińczyków za pośrednictwem własnych mediów, kierowanych zza granicy, i dla wielu z nich jest to jedyny przekaz niekomunistyczny, z jakim się stykają. Kampania zwalczania Falun dała władzom pretekst do przyjęcia formalnych rozwiązań prawnych, regulujących kwestie „szkodliwych kultów”. W październiku 1999 r. parlament promulgował ustawę zabraniającą heretyckich praktyk religijnych, służącą przeciwdziałaniu kultom i ich rozprzestrzenianiu. Przewiduje ona surowe kary dla przywódców ugrupowań religijnych, uznanych przez władze za szkodliwe dla porządku

${ }^{29}$ B. P. P it m a n, op. cit., s. 323.

${ }^{30}$ Szerzej o kampanii przeciwko Falun Gong patrz: J. T o n g, Anatomy of Regime Repression in China: Timing, Enforcement Institutions, and Target Selection in Banning the Falun Gong, July 1999, „Asian Survey” 2002, Vol. 42, Iss. 6, s. 795-820.

${ }^{31}$ H. H. L a i, op. cit., s. 65. 
społecznego. Sympatyków takich ugrupowań dokument nakazuje poddać reedukacji ${ }^{32}$.

Inne, nowe i niezarejestrowane ugrupowania już wcześniej padały ofiarą rządowych represji. Uznanie danej grupy za „szkodliwą sektę” często skutkuje surowymi wyrokami dla przywódców, z karą śmierci włącznie. Wiadomo o straceniu za działalność religijną w latach 1986-1999 26 osób $^{33}$. Do najbardziej znanych przywódców należą Wu Yangming, twórca inspirowanej chrześcijaństwem sekty Beiliwang (Króla Ustanowionego), stracony w 1995 r., oraz Liu Jiaguo, założyciel ruchu Zhushenjiao (Religii Boga Władcy). Wu szczególnie zasłynął ostrą krytyką protestanckiego związku religijnego, Liu zaś nawoływał do porzucenia życia doczesnego i nie angażowania się w pracę. Najszerzej zakrojone były represje wymierzone w ruch Yiguandao (Droga Wytrwałości), w ramach których w latach 1982-1985 stracono 17 osób w czterech prowincjach. Ten synkretyczny ruch, łączący konfucjanizm, taoizm, chiński buddyzm, nie odrzucający chrześcijaństwa i islamu, narodził się w czasach Republiki Chińskiej, a gwałtowny wzrost jego popularności w latach osiemdziesiątych zmusił władze komunistyczne do zdelegalizowania go, co rozpętało największą kampanię represji przeciwko ruchowi religijnemu do czasów Falun Gong. O skali religijnego ożywienia może świadczyć fakt, że w najludniejszej prowincji Henan w latach dziewięćdziesiątych zlikwidowano prawie 10 tysięcy „,szkodliwych sekt”, ${ }^{\text {, }}$.

Hu Jintao kontynuuje politykę swojego poprzednika i nadal prowadzi sprawy wyznaniowe zgodnie $\mathrm{z}$ wytycznymi marksistowskimi. Nowe regulacje prawne, dokument nr 426, który wszedł w życie w marcu 2005 r. - „Regulacje spraw religijnych" (Zongjiao Shiwu Tiaoli) - nie różnią się zasadniczo od dokumentów nr 19 i 145. Potwierdzają zasadę prymatu światopoglądu socjalistycznego i wymagają lojalności od przedstawicieli wszystkich grup i gmin religijnych, pragnących uzyskać czy też zachować rejestrację. Dokument 426 jest także kolejnym unikiem ze strony rządu, który uchyla się od opracowania stałego i konsekwentnego prawa religijnego ${ }^{35}$.

Dążeniem władz jest poddanie kontroli politycznej wszelkich przejawów życia religijnego. Tworzone prawodawstwo przybiera w tej kwestii formy zgoła absurdalne. 13 lipca 2007 r. BSR promulgowało rozporządzenie nr 5 „O sposobie administrowania reinkarnacją Buddy w buddyzmie tybetańskim" (Zangchuan Fojiao Huofo Zhuanshi Guanli Banfa). Dokument zawiera wzmiankę

${ }^{32}$ Angielski tekst tego dokumentu patrz: http://www.novexcn.com/stand_co-mit_cult_activ. html (stan z 4.11.2007).

${ }^{33}$ Dane Fundacji Dui Hua (Dialog) -,,Newsletter of the Dui Hua Foundation”, Fall 2002, Issue 9.

${ }^{34}$ H. H. L a i, op. cit., s. 67.

${ }^{35}$ H. P e t e r s e n, China: despite new Regulations, religious policy still under strain, Forum 18, News Service, 8 March 2006, http://www.forum18.org. 
o potrzebie chronienia wolności wyznania obywateli ChRL oraz odwołuje się do dokumentu 426 jako nadrzędnego prawa religijnego państwa. Punkt drugi dokumentu nakłada na reinkarnujących się obowiązek poszanowania jedności etnicznej kraju (sic!). Punkt piąty stanowi, że przed śmiercią mnisi muszą złożyć podanie o pozwolenie na reinkarnowanie się do lokalnych oddziałów związku religijnego bądź odpowiedniego wydziału rządu prowincjonalnego. Ten sam punkt nadaje związkowi wyznaniowemu rolę konsultacyjną w procesie decyzyjnym. Dokument nakłada także na mnichów obowiązek ścisłego raportowania wszelkich postępów w poszukiwaniu dziecka, w które mógłby się wcielić mnich. W przypadku „mających duży wpływ” osobistości należy poinformować bezpośrednio władze centralne ${ }^{36}$. Dokument wyklucza pozostających poza oficjalnym systemem związku wyznaniowego mnichów z procesu odnajdowania nowych wcieleń tulków oraz daje państwu możliwość represjonowania niezatwierdzonych młodych duchownych tybetańskich ${ }^{37}$.

Choć z pozoru dokument ten jest absurdalny w swojej próbie poddania kontroli politycznej mistycznego i duchowego procesu, jakim jest reinkarnacja w buddyzmie tybetańskim, ma służyć do realizacji oczywistych celów politycznych - uniemożliwienia niezależnym duchownym tybetańskim ogłoszenia kolejnych, niepodporządkowanych Pekinowi, Dalajlamy i Panczenlamy. Taką motywację władz potwierdził $\mathrm{w}$ rozmowie $\mathrm{z}$ niemieckim dziennikarzem Ye Xiaowen, który przyznał, że prace nad dokumentem nr 5 zostały podjęte w odpowiedzi na prośby tybetańskich buddystów, obawiających się „niezgodnych z tradycją machinacji separatystycznej kliki Dalajlamy"38. W ten paradoksalny sposób komunistyczne państwo chińskie uzurpuje sobie religijną prawowierność. W tym samym wywiadzie Ye odwołuje się do dynastii Yuan, Ming i Qing jako przykładów centralnych rządów chińskich, aprobujących wybory tybetańskich ,żywych Buddów”.

Wyznawcy religii wciąż są zobowiązani do całkowitej lojalności względem Partii i rządu, traktujących ich przekonania jako przeżytki, które zginą w miarę poszerzania się postępu. Kwestia swobód religijnych i wolności sumienia po dekadzie przemian gospodarczych nadal pozostaje w ChRL problemem delikat-

${ }^{36}$ Pełen tekst dokumentu: http://www.gov.cn/ziliao/flfg/2007-08/02/content_704414.htm, ( $\operatorname{stan}$ z 3.11.2007).

${ }^{37}$ Dokument nr 5 wywołał na świecie oburzenie, a jednocześnie pewne rozbawienie. W toczącej się dyskusji na jego temat nie zabrakło jednak i głosów znajdujących pewne zrozumienie dla władz chińskich, np. znanego słoweńskiego lewicowego filozofa Slavoja Žižka. Patrz. S. Ž i ž e k, How China Got Religion, New York Times; 11.10.2007.

${ }^{38}$ Ye Xiaowen Juzhang jiu „Zangchuan Fojiao Huofo Zhuanshi Guanli Banfa” Da Deguo Mingjing Zhoukan Jizhe [Dyrektor Ye Xiaowen odpowiada na pytanie dziennikarza tygodnika Der Spiegel dot. dokumentu „O sposobie administrowania reinkarnacją żywych buddów w buddyzmie tybetańskim”], http://www.sara.gov.cn/GB//xwzx/xwfb/5f94185c-7e1b-11dc-b574-93180af1bb1a. html. 
nym. Choć w kraju widuje się coraz więcej świątyń, przede wszystkim chrześcijańskich, członkowie wspólnot religijnych nie mogą liczyć na większą sympatię ze strony władz, nawet tych stworzonych do zarządzania kwestiami religijnymi, jak BSR. Problem religii w ChRL jest dobrym przykładem konserwatyzmu KPCh i jej oddania marksistowskiemu światopoglądowi. W obliczu dynamicznych zmian społecznych i gospodarczych w kraju, sytuacja ścisłej kontroli oficjalnych religii przez państwo i gwałtowny rozwój ruchów niezależnych, takich jak podziemny kościół katolicki czy dziesiątki mniejszych „szkodliwych kultów" pozwala w przyszłości oczekiwać dramatycznych wydarzeń. 